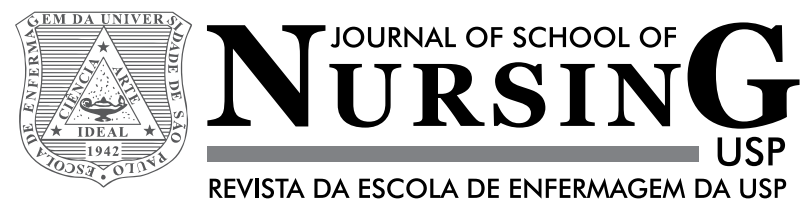

CRITICAL REVIEW

DOI: 10.1590/S0080-623420150000400021

\title{
Offshore work and the work of nurses on board: an integrative review*
}

\author{
Trabalho offshore e a atuação do enfermeiro embarcado: uma revisão integrativa \\ El trabajo offshore y la actuación del enfermero embarcado: una revisión integradora
}

\author{
Silvana Aline Cordeiro Antoniolli', Suzel Vaz Emmel', Gímerson Erick Ferreira², Potiguara de Oliveira Paz ${ }^{2}$, \\ Dagmar Elaine Kaiser ${ }^{1}$
}

\begin{abstract}
* Extracted from the final paper "Riscos ocupacionais na área petrolífera e atuação do enfermeiro offshore: uma revisão integrativa", Escola de Enfermagem, Universidade Federal do Rio Grande do Sul, 2014.

${ }^{1}$ Universidade Federal do Rio Grande do Sul, Escola de Enfermagem, Porto Alegre, RS, Brazil.

${ }^{2}$ Universidade Federal do Rio Grande do Sul, Escola de Enfermagem, Programa de PósGraduação em Enfermagem, Porto Alegre, RS, Brazil.
\end{abstract}

\section{ABSTRACT}

Objective: To know the production of theoretical approaches on issues related to offshore work and the work of offshore nurses. Method: Integrative literature review conducted in the databases of LILACS, BDENF, MEDLINE, SciELO and Index PSI. Results: We selected 33 studies published in national and international journals between 1997 and 2014. The thematic analysis corpus resulted in four central themes: offshore work environment; amid work adversities, an escape; structuring of offshore health and safety services; in search of safe practices. Conclusion: This study contributes to the offshore work of nurses in relation to the nature of work, acting amid adversities and the restless search for safe practices in the open sea.

\section{DESCRIPTORS}

Extraction and Processing Industry; Petroleum; Occupational Risks; Occupational Health Nursing; Occupational Health; Review. 


\section{INTRODUCTION}

The production and consumption of energy occupy important spaces, public or not, for discussing the political and economic trajectory of Brazil and the world. However, the role played by the oil industry goes far beyond the performance of its operating units apparently isolated on the open sea, or the importance of its derivatives for consumption. The exploration and production of oil in the sea involves a series of activities, including exploration and drilling, production of oil and conventional gas, extraction and processing of tar sands, oil processing operations, and heavy-oil pipelines ${ }^{(1)}$. It is a very specific kind of work due to its technological feature, human resources, the impending danger and confinement, i.e., workers remain in the workplace for consecutive days without absenting themselves even to sleep $^{(2)}$.

The offshore work occurs in offshore platforms, ranging from fixed platforms, semi-submersible platforms, which are floating structures that support a deck where probes, equipment, and staff accommodation are installed; or drillship, structures built or upgraded for drilling in very deep water ${ }^{(3)}$.

Depending on the roles they perform in the open sea workers are exposed to elements that affect their health and safety, and can also cause accidents or make them ill at work $^{(4)}$. Nurses are the only health professionals embarked on these platforms and they need to work with the imminent possibility of a disaster, be prepared to meet an unlimited number of injured or sick workers, in addition to the possibility of themselves becoming victims of a tragic occurrence.

Among other aspects, the Regulatory Norm number 30 $(\mathrm{NR}-30)^{(5)}$, originated in 1997 and reformed in 2002, 2010 and 2013, deals with health and safety at work on board of platforms and support facilities used for the purpose of exploration and production of oil and gas from the seabed. Despite all technological investment, accidents and illnesses are the daily reality of the oil sector ${ }^{(4)}$.

Thus, this article is derived from a study aimed to assess the production of theoretical approaches on issues related to offshore work and the work of offshore nurses, based on Brazilian and international publications in the period between 1997 and 2014, marked by the advent of NR-30, which regulated the work of offshore nurses and their practices.

\section{METHOD}

The integrative literature review gathers the results from other studies on the same subject to synthesize and analyze the data obtained by developing a more comprehensive explanation of the studied phenomenon ${ }^{(6)}$. The study was conducted in five steps. The first step comprised the problem formulation, deepening the characteristics of offshore work and the work of offshore nurses, recognizing the most important aspects that answered the guiding questions: What are the characteristics of offshore work? How do offshore nurses act in the context of oil rigs? The second step, data collection, was carried out in July 2014 and characterized the definition of search criteria in the following databases available online: the Virtual Health Library, integrating the Latin American and Caribbean Health Sciences (LILACS), the
International Database for Medical Literature (MEDLINE), the Nursing Database (BDENF), Virtual Health Library - Psychology Brazil (Index PSI) and the Scientific Electronic Library Online (SciELO), considering the scientific production between 1997 and 2014. We defined this period considering the beginning of norms for offshore work in Brazil. The descriptors used for online search were nursing, petroleum, risk, safety, labor and occupational health; registered on the Health Sciences Descriptors (DeCS). The inclusion criteria were all the national and international publications in Portuguese, Spanish and English that answered the guiding questions, comprising original research, experience reports and theoretical reflections in format of summary and full reports, available in the period between 1997 and 2014. All theses and dissertations were excluded. The third step was data evaluation, carefully considering the information contained in the articles, focusing on the guiding questions. The information was recorded identifying the publications by title, country of origin, language, authors and their titles, journal, year, descriptors submitted to the publication and research methodology. The study objective/ question and the studied population were observed as well, assigning a number to the publications found.

The fourth stage was data analysis based on thematic content analysis ${ }^{(7)}$. Data were initially identified in individual records, subsequently gathered in a summary table, and organized in a way to allow classification of the theoretical corpus on themes that emerged from the registration units identified. Then, data were discussed to contribute with new knowledge.

The intellectual property of consulted publications was respected with regard to the content and authorship, considering the copyright law ${ }^{(8)}$.

\section{RESULTS}

The results of this literature integrative review are shown to characterize the publications from 1997 to 2014, covering aspects related to the characteristics of offshore work and the work of offshore nurses in Brazil and worldwide. Initially, the search on the Virtual Health Library using the descriptors nursing, oil, occupational health, risk, safety and worker, did not identify any results. Then, a search was carried out using the descriptor oil, resulting in 11,568 occurrences. Table 1 shows the search results from crossing the descriptors.

After crossing the descriptors and applying the inclusion criteria, the search resulted in 111 works. However, the numerous readings of abstracts and papers resulted in the selection of 33 articles deeply related to the study. The results were grouped in the following pillars.

The national publications were from the following journals: Revista Brasileira de Saúde Ocupacional ${ }^{(9,33)}$, Ciência e Saúde Coletiva ${ }^{(10,19)}$,Uerj Nursing Journal ${ }^{(2,38)}$, Text \& Context Nursing ${ }^{(11)}$, Revista de Saúde Pública ${ }^{(20)}$, Reports in Public Health $^{(12,21-22,37)}$, Estudos de Psicologia de Campinas ${ }^{(3)}$ and Revista Psicologia Organizacional e do Trabalho ${ }^{(13)}$. The following international journals stood out: Occupational Environmental Medicine $e^{(14,17,25-26,34-36)}$, Morbidity and Mortality Weekly 
Report $^{(15)}$, Work ${ }^{(16,18,23-24)}$, BMC Public Health, Scandinavian Occupational Medice ${ }^{(1,28,31)}$, International Archives of Occupational Journal of Work Environmental E Health ${ }^{(29)}$, Journal Sleep ${ }^{(32)}$, Environmental Health ${ }^{(30)}$ and Acta Médica Peruana ${ }^{(27)}$.

Table 1 - Publications resulting from the search for descriptors - Porto Alegre, RS, Brazil, 2014.

\begin{tabular}{|c|c|c|c|c|c|c|c|c|c|c|}
\hline Databases & Oil & $\begin{array}{c}\text { Human } \\
\text { engineering / } \\
\text { Oil / Worker }\end{array}$ & $\begin{array}{l}\text { Oil / Human } \\
\text { engineering }\end{array}$ & $\begin{array}{l}\text { Oil / } \\
\text { Safety / } \\
\text { Worker }\end{array}$ & $\begin{array}{c}\text { Oil / } \\
\text { Risk / } \\
\text { Worker }\end{array}$ & $\begin{array}{c}\text { Oil / } \\
\text { Occupational } \\
\text { health }\end{array}$ & $\begin{array}{l}\text { Occupational } \\
\text { health }\end{array}$ & Risk & $\begin{array}{l}\text { Total } \\
\text { articles } \\
\text { found }\end{array}$ & $\begin{array}{c}\text { Total } \\
\text { articles } \\
\text { selected }\end{array}$ \\
\hline MEDLINE & 23 & 03 & 06 & 06 & 04 & 09 & 01 & 01 & 53 & 21 \\
\hline LILACS & 17 & 01 & 01 & 09 & 09 & 03 & 07 & 03 & 50 & 07 \\
\hline BDENF & 02 & - & - & - & - & - & - & - & 02 & - \\
\hline SCieLO & 01 & & & & & & 01 & 02 & 04 & 04 \\
\hline Index Psi & 01 & 01 & - & - & - & - & & & 02 & 01 \\
\hline \multicolumn{9}{|l|}{ TOTAL } & 111 & 33 \\
\hline
\end{tabular}

Source: Virtual Health Library.

Table 2 - Central themes and registration units of the study - Porto Alegre, RS, Brazil, 2014.

\begin{tabular}{|c|c|}
\hline CENTRAL THEMES & REGISTRATION UNITS \\
\hline Offshore work environment & $\begin{array}{l}\text { Dichotomy work environment/domestic environment }{ }^{(9-10)} \\
\text { Nature of work on board }{ }^{(2,9-18)} \\
\text { Exposure to occupational risk } \\
\text { Safi-3,9-13,16,18-32) } \\
\text { Saty ark } \text { work }^{(2,-10,12,15)}\end{array}$ \\
\hline Amid work adversities, an escape & $\begin{array}{l}\text { Work accidents }{ }^{(2,9,11-12,15,17,33)} \\
\text { Illness at work }^{(13-14,17,19,22,25,27-30,32-37)} \\
\text { Absenteeism } \\
(33-34,37)\end{array}$ \\
\hline \multirow[t]{2}{*}{ Structuring of offshore health and safety services } & $\begin{array}{l}\text { Offshore work in health and safety }{ }^{(1,17)} \\
\text { The work of offshore nurses }{ }^{(2,11,38)} \\
\text { Litter team } 111)\end{array}$ \\
\hline & Rescue of offshore victims with use of helicopters ${ }^{(1,3,12,15,17,25,35-36,38)}$ \\
\hline \multirow{2}{*}{ In search of safe practices } & Legislation $^{(1-2,9-10,15,24,27,33)}$ \\
\hline & Development programs $\mathbf{s}^{(1,12-13,15,18-19,22-25,27,33,37)}$ \\
\hline
\end{tabular}

Source: Research data.

\section{DISCUSSION}

The offshore work, mainly because of consecutive days on the vessel, in a very restricted space and organized in shifts, either in terms of engine noise, weather conditions or lack of comfortable accommodation, refers to an intense work in oil rigs. This type of work must be established and documented, covering described work processes that specify the duties and responsibilities of the labor force, as well as the workers' health and safety, environmental impact and ambience.

\section{OfFSHORE WORK ENVIRONMENT}

This theme addresses the important situations related to the hybrid structure of the workplace/domestic environment, nature of work on board, exposure to occupational risk, and safety at work.

\section{DICHOTOMY WORK ENVIRONMENT/DOMESTIC ENVIRONMENT}

The offshore work presents peculiarities that refer to the workers' production on consecutive days per month, normally in shifts of 14 days of continuous work on board, and 21 days off in the familiar environment, returning home only after completing the period on-duty ${ }^{(9)}$. Undoubtedly, the offshore work disrupts the social life and has implications for health and social coexistence ${ }^{(9-13)}$. With regard to social repercussions, note that for workers, time does not have the same value in the different hours of the day nor in the different days of the week. The subjective value of nighttime is assumedly the most appreciated in relation to family life. Although coordinating working hours and the time of family life is customary for workers in general, it is not so for offshore workers ${ }^{(9)}$.

The dichotomy work/domestic environment alerts to two aspects or the sum of both: the psychic and emotional state of workers and the specifics of the role and work. The behaviors adopted by workers in the effective exercise of their professional activities may interfere with moments of the life on board, and the opposite movement can occur. Such lack of dissociation creates a situation of constant vigilance that can have tragic repercussions for health, pushing the mobilization capacity to the limit in face of the situation ${ }^{(13)}$.

The offshore work also affects the family unit ${ }^{(9-10,38)}$ that experiences suffering and distress, requiring the elaboration of living for illness prevention.

\section{NATURE OF WORK ON BOARD}

The work at open sea is not focused solely on productivity and profit, but goes much further, as it deals with the own personality and life goals of individuals. If these aspects are taken into account at work, they can bring satisfaction, well-being and reverberate in offshore productivity. The work on oil rigs consists of four aspects that are in- 
terrelated and characterize it: simultaneously continuing; complex; collective; dangerous. Continuous, since the production flows during 24 hours a day throughout the year, with rotation of various groups of workers to be able to cope with the activity. Complex, because the devices are interconnected on a network that prevents the total control of the work process, with unpredictable incidents and accidents. Collective, given that the oil rig operation is only made possible by the work teams, whose activities are highly interdependent. And finally dangerous, because the work is related to the processing of hydrocarbons that evaporate, ignite or explode; the use of toxic chemicals; and operation of machinery and equipment that can trigger accidents with significant potential for multiple injuries and deaths ${ }^{(12)}$.

Thus, in the work on board the employees have to deal with numerous adversities, such as the absence of social and family life during offshore time ${ }^{(9)}$, insufficient sleep, accurate attention and wakefulness ${ }^{(12)}$, dyssynchrony between time and chronobiological effects ${ }^{(9,13)}$, and relationships of conflict $^{(12)}$. However, each worker brings their uniqueness in this come-and-go movement that characterizes the offshore work $^{(9)}$, strongly defined by the need for security, personal and social inter-relationship and use of extreme physical and psychological capabilities ${ }^{(10)}$.

\section{EXPOSURE TO OCCUPATIONAL RISK}

The general idea is that the operation in oil platforms is safe and failures are sporadic and occasional. In offshore work, risk refers to the technical, collective and environmental demands related to technological events and organizational conditions or those of natural origin aggravated by technology, often victimizing or with the potential to victimize workers and communities in and outside oil platforms, resulting in significant environmental changes ${ }^{(10)}$. These concerns indicate that the exploitation of oil and gas, drilling of production wells, air and maritime transport, repair, construction and reform, shallow and deep dives ${ }^{(12)}$ in all its stages, the various and intrinsic risks inherent in the reciprocity among technical factors, human conditions and natural environment changes are part of the daily routine in the open sea ${ }^{(19)}$.

The workers think and act in accordance with their knowledge, experiences and impressions of the risk, establishing a peculiar knowledge with it ${ }^{(21)}$.

Offshore workers are exposed to various occupational hazards in the workplace, some noticeable and others not. The risk assessment involves three basic steps: identification of hazards; estimation of risk in each hazard and decision if the risk is tolerable. According to the Pan American Health Organization $^{(39)}$, occupational hazards can be classified as chemical, biological, ergonomic (psychosocial and mechanical), of accidents and physical.

In the studied articles, it was identified ${ }^{(11-27)}$ that the risk of exposure to loud noise, vibration, excessive heat, work performed in the open air and use of offshore work tools are physical risks to which workers are subjected at work, including exposure to bad weather such as rain, wind, sun and temperature fluctuations.
Inhalation of vapors or even dermal contact with crude oil, intermediate and end products, characterize exposure to chemical risks ${ }^{(11,27,30)}$. The biological hazards were identified as being related to poor hygiene, resulting in food poisoning, a typical manifestation of biological hazards in the offshore workplace, or to disturbances of biological rhythm due to shift work $^{(11)}$. The airborne diseases spread rapidly through ventilation systems on offshore installations ${ }^{(27)}$.

The exposure to ergonomic hazards is a consequence of adopting inadequate and forced postures in the offshore work, also known as mechanical hazards ${ }^{(27)}$. With regard to psychosocial risks, the stressors such as workload, lack of clarity at work, frequent changes ${ }^{(27)}$, confinement at open sea, the lifestyle imposed on workers, and the mental effects of these factors ${ }^{(11)}$ are everyday examples.

The work on the platform by itself is already dangerous $^{(12)}$, and increasingly collective, because the deleterious effects of the oil activity tend to spread, sometimes affecting not only the workers more directly involved in the labor process, but also the administrative staff and even the local population in nearby regions.

The risk of accident is identified by the routine nature of the work and by the ignorance of managers who work on land about what constitutes offshore work ${ }^{(12)}$. These factors can exacerbate the dissatisfaction of platform workers with the administrative management.

\section{SAFETY AT WORK}

Considering the occupational hazards present in offshore work, a critical danger is visible, either by working with sleep deprivation, fatigue and need for performing tasks that require continuous attention and alertness ${ }^{(9)}$, or the fact that even though workers know the risks to which they are exposed, they not always adhere to safety and security measures ${ }^{(25)}$. The low use of personal protective equipment and its mishandling are justified by discomfort, nuisance, carelessness, forgetfulness, lack of habit, inadequate equipment, insufficient quantity and disbelief of its use. Moreover, these factors are aggravated by the lack of knowledge and poor infrastructure ${ }^{(40)}$.

Procedures such as inspections and checks, certification and calibration of equipment and instruments, measurements of corrosion, of material integrity and geometry of parts, technical inspection after deformation, fracture or breakage of parts, as well as chemical, physical and environmental measurements are crucial for accident prevention. Failure to observe these aspects makes safety unavailable and workers exposed to different risks resultant from the work process ${ }^{(12)}$.

Prevention practices are fundamental for reducing accidents on oil rigs. For a safe and complete evacuation in case of a major accident, preventive aspects need to be observed. There needs to be at least an intact escape route among the main work areas, offering protection from fires and explosions and keeping acceptable internal conditions for a specified time. Furthermore, there should be sufficient lifeboats located near the escape route ${ }^{(13)}$, capable of accommodating the entire platform personnel. 


\section{AMID WORK ADVERSITIES, AN ESCAPE}

In face of occupational hazards present in offshore work and with all efforts for workers' health and safety, accidents and illness at work are relevant facts that have marks of this violence in the productive restructuring, resulting at best, in absenteeism ${ }^{(38)}$.

\section{WORK ACCIDENTS}

Many accidents have occurred in the oil industry history, sometimes given the deficient risk management of machinery, workers' action and responsibility of manag$\mathrm{ers}^{(12,38)}$. The risk of accident is present in each of the three phases of hydrocarbons production at sea: the extraction, hydrocarbon processing on the platform and in the pumping of oil for tankers. In this sense, it is necessary to constantly invest in equipment, apply innovative technologies, improve the quality of materials used, and strictly observe the offshore platform safety to minimize the risk of accidents ${ }^{(38)}$. Another measure is to invest in human resources development by choosing means for combating accidents and their consequences in cases they cannot be prevented. However, such measures only minimize the risks of accidents $^{(12)}$, and it is necessary to admit the permanent probability of their occurrence.

Despite the established safety standards in the offshore environment, accidents victimizing a large numbers of workers at the same time happen, which are cases of real catastrophes with explosion and subsequent sinking of the platform. Historically, these events have been taking place in Brazil and worldwide, as happened with the Brazilian platform of Enchova in 1984 (12), of the Petrobras P-36 in 2001 ${ }^{(12)}$, in the platform of Piper-Alpha in the United Kingdom in 1988 ${ }^{(12)}$, the environmental disaster of the Deepwater Horizon platform, in the Gulf of Mexico in $2010^{(20)}$, and more recently, the tragic accident involving the Brazilian floating vessel called FPSO Cidade São Mateus of Petrobrás, in February 2015, reported in the world media.

\section{ILLNESS AT WORK}

For workers, offshore work offers eminent risk for developing specific diseases. These diseases are triggered by several factors such as confinement, night work, sleep disorders, stress, lifestyle, exposure to chemicals and physical exertion, which make offshore workers susceptible to occupational diseases.

The illness of workers on board is related to lifestyle, and is a consequence of improper diet, obesity, smoking, alcohol and physical inactivity. This lifestyle results in coronary artery disease, high blood pressure and metabolic syndrome $^{(19-20,34)}$. The musculoskeletal disease is the one that most affects offshore workers ${ }^{(25)}$.

Exposure to high levels of noise for a short period of time can trigger cardiovascular responses similar to those occurring in acute stress situations, with increased blood pressure. The occupational noise exposure seems to be a risk factor for high blood pressure and contributes to hearing loss ${ }^{(37)}$.
When workers lose control over their organization of time, and start to cope with consecutive shift changes, extended work shifts, and fast rotations in days of rest, their mental health may be at risk, and aspiration levels at work may be among the causes of stress, producing anxiety. $\mathrm{Di}-$ rectly or indirectly, occupational stress causes psychosomatic and physiological problems such as mental disorders, cardiovascular diseases, musculoskeletal pain and gastrointestinal disorders. These effects can be moderated by other psychosocial factors such as the coping style ${ }^{(26)}$.

As workers are exposed to high toxicity chemicals, they are more likely to fall ill from cancer, with lung, skin, prostate, bladder and kidney cancer as the most prevalent types. Leukemia is a disease of particular concern in this industry because of its association with exposure to benzene. The causes of these cancers are related not only to the workplace, but also to the roles played, showing that exposure to specific agents has significant relation with the development of disease or $\operatorname{not}^{(14,30,32,35-36)}$.

Shared work is necessary for a proper evaluation of the workers' health, as well as the collaboration between offshore nurses and managers in the search for safety and access to health education. In addition, the regulatory agencies should be more prudent and make more incisive demands to those in charge ${ }^{(11)}$. The attention with workers' health may represent changes, such as improved ability to predict and model the potential health risks, the development of health functions capable of integrating with the project development and ensuring that barriers against health risks are strengthened, while actions for the health of workers are developed ${ }^{(27)}$.

\section{ABSENTEEISM}

Absenteeism is when the employee is absent from work by illness, accident or medical procedure justified by medical leave due to an individual's disability, during the sick leave period $^{(21)}$. In any of its forms, absenteeism has been a major problem in offshore work, becoming a concern for both the oil industry and its managers. It is caused by multiple factors, making this issue complex and of difficult management, with quantitative impact for offshore workers by frequent absences from work, in addition to reflecting on offshore productivity, generating important economic impact ${ }^{(21)}$.

Studies ${ }^{(2,34)}$ indicate that absences in offshore work are caused by diseases of the musculoskeletal system and connective tissue, followed by diseases of the digestive and respiratory systems. The main causes of longer work leaves are diseases of the ear and mastoid apophysis, mental and behavioral disorders, injuries, poisoning and certain consequences of external causes, often aggravated by poor access to health services. There was no reference to absenteeism as an escape amid the adversities of offshore work.

\section{STRUCTURING OF OFFSHORE HEALTH AND SAFETY SERVICES}

The oil rig is organized like a city, with its operational and support characteristics necessary for the uninterrupted 24-hour operation. The health and safety space is devel- 
oped for establishing health promotion actions for workers exposed to risks, regardless if they are sick, or healthy. Within this context stand out the offshore work in health and safety, work of offshore nurses, litter team and rescue of offshore victims with use of helicopters.

\section{OFFSHORE WORK IN HEALTH AND SAFETY}

The work on oil platform demands that employers and workers pay special attention to health and safety in the offshore space, requiring caution with individual, collective, social and managerial aspects, which often indicates the proactive need for change in certain offshore aspects. A clear implication of this movement is the need to reduce the exposure of workers and the environment to risks, and not exposing the collective to imminent situations and risks ${ }^{(17,27)}$.

Thus, for the proper development of work processes on oil platforms, there is clear need for adjustments and changes, covering the health and safety of workers and oil installations, to ensure the reduction of injuries to workers' health, by sharing work between the occupational health staff and offshore workers.

\section{THE WORK OF OFFSHORE NURSES}

The offshore health field is extremely broad and shared by many professionals in various health areas and spaces. Within this context, the nurses represent a trend of the world and national labor market in the oil industry. Offshore nurses on oil rigs represent the offshore health in a new and economically labor market desired by its social and economic representation, and because it manufactures essential products to contemporary life ${ }^{(27)}$.

In the offshore environment, the nurses perform activities related to the job on board for a confined period, on a rota of 14 continuous workdays offshore, and 14 days off with a daily workload of 12 hours $^{(11,38)}$. They are responsible for the same technical duties of the profession, and for a competent performance, they engage in health prevention, promotion and recovery, and in situations of emergency. Offshore nurses manage their activities based on the company job description, and their knowledge and ability support their leadership attitude in all spaces ${ }^{(18)}$.

Thus, the nurses participate in the planning, implementation and evaluation of programs that ensure continuous actions and enable the health and safety of workers on board in the offshore oil industry. These professionals promote care, health guidance and sanitary inspections in loco, aiming at health promotion strongly articulated with the safety of offshore work. Certainly an innovative, specific and complex task, representing a great challenge for nursing. There are few studies on the performance of nurses on oil rigs $^{(10,38)}$. Hence, more discussions and knowledge are needed for this professional expansion, for the offshore work process where nurses are inserted, and about how nurses maintain their capabilities in the labor market and before society in general.
LITTER TEAM

There is a health and safety team in the oil rigs that promotes the health and safety of workers articulatedly in this space. Nurses are the only health professionals in this team and in emergency conditions, they lead a group of employees identified as litter team, enabled for emergency actions $^{(11)}$. Therefore, offshore nurses must be prepared to act in different situations of health and safety, and in actions for preventing and promoting their health, based on the situational analysis of the work environment, in cooperation with the specialized health and safety service of the company $^{(38)}$.

In the offshore platform, health guidance activities are developed specifically in the health briefing for crew members through health talks held weekly, together with safety lectures during the training for the litter team. Thus, the initial briefing upon entrance on the platform brings information and instructions relating to the current ongoing operation, about the actions in terms of the drilling phase of the wells, and if accidents have happened recently or not. Such briefings also address incidents, indicate and ratify safety measures without exposing workers ${ }^{(11)}$.

The offshore nurses establish therapeutic listening and preventive care based on nursing diagnosis during assistance to workers. However, in situations of emergency in the oil rigs, since nurses are the only health professionals on board, they perform first aid services and lead the litter team. They use the call center by phone or video conference to share the health care needs with the occupational doctor of the industry, who guides the treatment and makes the prescription far from the platform ${ }^{(11)}$. In the offshore platform, nurses perform activities using the knowledge to manage health actions in the open sea and promote the health and well-being of workers in the offshore environment. For this reason, they must keep their knowledge updated for acting in extreme and routine situations in the work on board, and manage the litter team in cases of emergency.

\section{RESCUE OF OFFSHORE VICTIMS WITH USE OF HELICOPTERS}

In the event of serious accidents, there is concern with reducing the number of victims and due to that, all workers should act to minimize or resolve the existing dangers related to physical, chemical, biological and ergonomic risks, both psychosocial and of the accident ${ }^{(36)}$. Given that platform installations operate far from the coastline, they need a certain degree of autonomy. This location implies a set of coordinated actions to keep the services of food and accommodation for the crew on board, as well as supply of water, energy, transport by boat or helicopter, medical services and communication, among others ${ }^{(13)}$. In this context, the offshore nurse has an essential role in providing first aid with the litter team, and by calling the rescue team, who reaches the accident site by helicopter ${ }^{(38)}$. In medical emergency evacuations, and with helicopters on board, even though the crew is responsible for providing a certain level of medical care and equipment ${ }^{(17)}$, the role of nurses is $\mathrm{key}^{(10)}$. In accidents on oil rigs, the helicopter crew joins the 
offshore work, and the air transport of workers on board is equally subject to accidents. The rescue of injured people requires agile work on the helicopter, but the security of those transported and the crew must be a priority at this time. In an attempt to reduce deaths during the rescue, the strictest security measures must be guaranteed in air operations ${ }^{(25,27,38)}$.

\section{IN SEARCH OF SAFE PRACTICES}

This theme presents aspects that can strongly help with the adoption of safe practices by offshore workers, considering the current legislation and development programs.

\section{LEGISLATION}

The work in the oil industry has laws that support and provide elements for offshore work. Among the studied articles $^{(10-11,24,38)}$, many documents stand out in the literature by addressing the health and safety of offshore workers. The law number 5.811/72, establishes guidelines for the work under a special system of continuous shifts and on call, destined for the oil industry ${ }^{(11)}$. The Collective Bargaining Agreement of 1989, signed between Petrobras and the union of oil workers, regarding the offshore regime with the working hours of 12 hours for 14 days, landing on the fifteenth day and with 21 days off ${ }^{10)}$. The ANP Resolution number 43/2007, of the National Agency of Petroleum, Natural Gas and Biofuels (ANP) on Technical Regulation of Operational Safety and Management System for Maritime Drilling Installations and Oil and Natural Gas (29). The ordinance number 3.214 , of June 8,1978 , of the Ministry of Labor and Employment deals with specific mandatory norms for the oil work. The Regulatory Norm number 4 (NR-4) regulates the need for the Service of Safety and Occupational Medicine (SESMT - Serviço de Segurança e Medicina do Trabalho) in the oil sector. The actions of this service specialized in health and safety are established from two programs, namely: the environmental program called Environmental Risk Prevention Program (PPRA - Programa de Prevenção de Riscos Ambientais) and another program named Medical Control Program of Occupational Health (PCMSO - Programa de Controle Médico de Saúde Ocupacional), which offer excellent opportunity for the promotion, protection and recovery of health ${ }^{(38)}$. The NR-12 includes security measures for machines and safety equipment, the NR-17 deals with the ergonomics of the workstation, manual labor and material of treatment modalities, and the NR-26 concerns the safety signs ${ }^{(29)}$. The NR-29 brought attention to the work in ports ${ }^{(21)}$. Special emphasis was given to the NR-30 on the protection and regulation of health and safety conditions of waterway workers, and the NR-32 establishes basic guidelines for the implementation of protection measures for the health and safety of workers in health services. The norms for vessels engaged in open sea navigation, especially the NORMAN-01 and the Ordinance number 72/2009 provide that for a safe operation, every vessel or platform shall have a minimum number of crew members associated with a qualitative and quantitative distribution for the safe work, called safety crew. It also establishes that the presence of a nursing professional in the health section of maritime units is mandatory. The NR-33 deals with confined space, which is any area or environment not designed for continuous human occupation, with limited means of entry and exit, and insufficient ventilation to remove contaminants or anything that interferes with air quality ${ }^{(11)}$.

It is essential to understand the context of the legislation to apprehend its goals, but that alone is not enough. Despite the efforts to establish offshore protection norms, especially on occupational exposure and risk of accidents, there are still irregularities in compliance, requiring greater control of safety standards according to laws, decrees, resolutions, collective agreements and regulatory norms, for a safer exploration and production of oil and gas.

\section{DEVELOPMENT PROGRAMS}

The oil industry has strong representation in the world market, and it is necessary to go beyond the exploitation of oil fields to remain in the ranking of productivity, ensuring, among other demands, the development of programs aimed at comprehensive health and safety in the offshore work. In the group of publications forming the theoretical corpus of this article, the authors corroborate the need to develop the offshore workforce ${ }^{(19,21,26-27,34,37)}$. In addition to traditional elements of work, such as preventive and protective measures related to work organization, management of production and direct implications on the risk of accidents, these development programs should also include advice and support to programs for the workers' welfare as weight reduction, smoking cessation, stress management and personal fitness ${ }^{(34)}$.

The creation of health environments that enable the excellence of nursing care promotes the development of shared working partnerships and collaborations between nurses and managers in search for innovation and entrepreneurship in nursing practice ${ }^{(41)}$, which is a differential for the prevention and promotion of offshore health in the presence of most environmental and occupational risks $^{(17,30,41)}$, considering the harms to the health of workers and the environment.

\section{CONCLUSION}

Proper working conditions in the extraction and production of oil at sea, such as an oriented litter team, immediate air rescue, adoption of safe practices and the personality of offshore workers could answer the guiding questions of the present study. However, we must reflect on the complex and dangerous offshore work that occupies an important discussion space in the political and economic trajectory worldwide and in Brazil, where the presence of nurses is essential.

Nurses have specific duties in the offshore work and are the only health professionals on board. In the oil rigs, their presence is a professional reference in the area of health and safety of workers. The fascination behind offshore work is a consequence of this being a different and very cost-effective 
workplace that ensures social prestige in a certain way. However, the side of a lonely job, in confinement, carried out in continuous shifts, either outdoors or at night, facing the weather at open sea, under extreme stress triggered by this work, away from family and the access to health resources and society is scarcely published and advertised.

Studies in the area of Occupational Health Nursing must increasingly deepen the work processes from different areas of coverage, design and characteristics, aiming at different forms of knowledge production in terms of organizational practice and guidelines for action, in order that tragic repercussions as accidents with oil platforms reported in the world media are minimized, and if possible, eliminated. There is little research on the work of offshore nursing, so this is a fertile field for studies.

The present study contributes to the realization of development programs for the offshore workforce by changing from the assistance focus to more specific and resolving alternatives for the completeness of health and safety of workers and the environment at open sea. The results cover important aspects when exploiting data that can help the society to reflect on the matter and invest in the consolidation of healthy environments, with the own offshore worker as protagonist.

\section{RESUMO}

Objetivo: Conhecer a produção de abordagens teóricas sobre aspectos relacionados ao trabalho offshore e a atuação do enfermeiro embarcado. Método: Revisão integrativa da literatura realizada nas bases de dados LILACS, BDENF, MEDLINE, SciELO e Index PSI. Resultados: Foram selecionados 33 estudos publicados em periódicos nacionais e internacionais, entre 1997-2014. Do corpus da análise temática resultaram quatro temas centrais: ambiente de trabalho offshore; em meio às adversidades do trabalho, uma fuga; estruturação dos serviços de saúde e segurança offshore; em busca de práticas seguras. Conclusão: O presente estudo traz contribuições ao trabalho offshore do enfermeiro quanto à natureza do trabalho, o agir em meio às adversidades e a incessante busca por práticas seguras em alto-mar.

\section{DESCRITORES}

Indústrias Extrativas e de Processamento; Petróleo; Riscos Ocupacionais; Enfermagem do Trabalho; Saúde do Trabalhador; Revisão.

\section{RESUMEN}

Objetivo: Conocer la producción de abordajes teóricas acerca de los aspectos relacionados con el trabajo offshore y la actuación del enfermero embarcado. Método: Revisión integradora de la literatura realizada en las bases de datos LILACS, BDENF, MEDLINE, SciELO e Index PSI. Resultados: Fueron seleccionados 33 estudios publicados en periódicos nacionales e internacionales, entre 19972014. Del corpus del análisis temático resultaron cuatro temas centrales: ambiente laboral offshore; en medio de las adversidades del trabajo, una fuga; estructuración de los servicios de salud y seguridad offshore; en búsqueda de prácticas seguras. Conclusión: El presente estudio brinda contribuciones al trabajo offshore del enfermero en cuanto a la naturaleza del trabajo, la actuación en medio de las adversidades y la incesante búsqueda de prácticas seguras en alta mar.

\section{DESCRIPTORES}

Industria Procesadora y de Extracción; Petróleo; Riesgos Laborales; Enfermería del Trabjo; Salud Laboral; Revisión.

\section{REFERENCES}

1. Niven K, McLeod R. Offshore industry: management of health hazards in the upstream petroleum industry. Occup Med [Internet]. 2009 [cited 2014 July 12];59(5):304-9. Available from: http://occmed.oxfordjournals.org/content/59/5/304.full.pdf+html

2. Guedes CCP, Aguiar BGC, Tonini T. Características do ambiente de trabalho do enfermeiro em plataforma de petróleo offshore. Rev Enferm UERJ [Internet]. 2011 [citado 2014 jul. 12];19(4):657-62. Disponível em: http://www.facenf.uerj.br/v19n4/v19n4a26.pdf

3. Barbosa SC, Borges LO. Saúde mental e diferentes horários de trabalho para operadores de petróleo. Estud Psicol. 2011;28(2):163-73.

4. Gurgel AM, Medeiros ACLV, Alves PC, Silva JM, Gurgel IGD, Augusto LGS. Framework dos cenários de risco no contexto da implantação de uma refinaria de petróleo em Pernambuco. Ciênc Saúde Coletiva [Internet]. 2009 [citado 2014 jul. 12]; 14(6):2027-38. Disponível em: http://www.scielo.br/pdf/csc/v14n6/10.pdf

5. Brasil. Ministério do Trabalho e Emprego. Portaria SIT n. 100, de 17 de janeiro de 2013. Norma Regulamentadora NR- 30: dispõe sobre segurança e saúde no trabalho aquaviário [Internet]. Brasília; 2013 [citado 2014 dez. 17]. Disponível em: http://portal.mte.gov.br/data/fi les/8A7C816A4AC03DE1014AE95913121041/NR-30\%20\%28atualizada\%202015\%29.pdf

6. Cooper HM. Scientific guidelines for conducting integrative research reviews. Rev Educ Res. 1982;52(2):291-302.

7. Gomes R. A análise de dados em pesquisa qualitativa. In: Minayo MCS. Pesquisa social: teoria, método e criatividade. Petrópolis: Vozes; 2002. p. 67-80

8. Brasil. Lei n. 12.853, de 14 de agosto de 2013. Altera, atualiza e consolida a legislação sobre direitos autorais e dá outras providências [Internet]. Brasília; 2013 [citado 2014 maio 14]. Disponível em: http://www.planalto.gov.br/ccivil_03/leis/l9610.htm

9. Alvarez D, Figueiredo M, Rotenberg L. Aspectos do regime de embarque, turnos e gestão do trabalho em plataformas offshore da Bacia de Campos (RJ) e sua relação com a saúde e a segurança dos trabalhadores. Rev Bras Saúde Ocup [Internet]. 2010 [citado 2014 jul. 12];35(122):201-16. Disponível em: http://www.scielo.br/pdf/rbso/v35n122/a04v35n122.pdf

10. Leite RMSC. Vida e trabalho na indústria de petróleo em alto mar na Bacia de Campos. Ciênc Saúde Coletiva [Internet]. 2009 [citado 2014 jul. 12];14(6) 2181-9. Disponível em: http://www.scielo.br/pdf/csc/v14n6/25.pdf 
11. Amorim GH, Guedes MAS, Guedes CCP, Aguiar BGC. Enfermeiro embarcado em plataforma petrolífera: um relato de experiência offshore. Texto Contexto Enferm [Internet]. 2013 [citado 2014 jul. 12];22(1):257-65. Disponível em: http://www.scielo.br/pdf/tce/v22n1/pt_31.pdf

12. Freitas CM, Souza CAV, Machado JMH, Porto MFS. Acidentes de trabalho em plataformas de petróleo da Bacia de Campos, Rio de Janeiro, Brasil. Cad Saúde Pública [Internet]. 2001 [citado 2014 jul. 12];17(1):117-30. Disponível em: http://www.scielo.br/pdf/csp/v17n1/4067.pdf

13. Barbosa SC, Borges LO, Nascimento IS, Melo AAF, Silva AKL. O trabalho dos operadores de produção de petróleo norte-riograndenses. Rev Psicol Organ Trab. 2006;6(2):111-37.

14. Kirkeleit J, Riise T, Bjorge T, Moen BE, Bratveit M, Christiani DC. Increased risk of oesophageal adenocarcinoma among upstream petroleum workers. Occup Environ Med [Internet]. 2010 [cited 2014 July 12];67(5):335-40. Available from: http://www.ncbi.nlm.nih.gov/pmc/ articles/PMC3728278/?tool=pubmed

15. Frieden RT. Fatal Injuries in Offshore Oil and Gas Operations - United States, 2003-2010. MMWR Morb Mortal Wkly Rep. 2013;62(16):301-4.

16. Conceição C, Silva G, Broberg O, Duarte F. Intermediary objects in the workspace design process: means of experience transfer in the offshore sector. Work. 2012;41 Suppl 1:127-35.

17. Donnelly R. The offshore industry: overview. Occup Med [Internet]. 2009 [cited 2014 July 12]; 59:296-7. Available from: http://occmed. oxfordjournals.org/content/59/5/296.full.pdf+html

18. Waage S, Moen BE, Pallesen S, Eriksen HR, Ursin H, Akerstedt T, Bjorvatn B. Shift work disorder among oil rig workers in the North Sea. Sleep [Internet]. 2009 [cited 2014 July 15];32(4):558-65. Available from: http://www.ncbi.nlm.nih.gov/pmc/articles/PMC2663659/

19. Felipe-de-Melo ERT, Silva RCR, Assis AMO, Pinto EJ. Fatores associados à síndrome metabólica em trabalhadores administrativos de uma indústria de petróleo. Ciênc Saúde Coletiva [Internet]. 2011 [citado 2014 jul. 12];16(8):3443-52. Disponível em: http://www.scielo.br/ $\mathrm{pdf} / \mathrm{csc} / \mathrm{v} 16 \mathrm{n} 8 / \mathrm{a} 12 \mathrm{v} 16 \mathrm{n} 8 . \mathrm{pdf}$

20. Oenning NSX, Carvalho FM, Lima VMC. Risk factors for absenteeism due to sick leave in the petroleum industry. Rev Saúde Pública [Internet]. 2014 [cited 2014 July 12];48(1):103-22. Available from: http://www.scielo.br/pdf/rsp/v48n1/en_0034-8910-rsp-48-01-0103.pdf

21. Soares JFS, Cezar-Vaz MR, Mendoza SRA, Almeida TL, Muccillo BAL, Soares MCF, et al. Percepção dos trabalhadores avulsos sobre os riscos ocupacionais no porto do Rio Grande, Rio Grande do Sul, Brasil. Cad Saúde Pública [Internet]. 2008 [citado 2014 jul. 12]; 24(6):1251-9. Disponível em: http://www.scielo.br/pdf/csp/v24n6/06.pdf

22. Fernandes RCP, Carvalho FM. Doença do disco intervertebral em trabalhadores da perfuração de petróleo. Cad Saúde Pública [Internet]. 2000 [citado 2014 jul. 12];16(3):661-9. Disponível em: http://www.scielo.br/pdf/csp/v16n3/2951.pdf

23. Oggioni B, Duarte F, Cordeiro C. Ergonomics in projects of oil platforms in a change context. Work. 2012;41:107-13.

24. Robb M, Miller G. Human factors engineering in oil and gas: a review of industry guidance. Work. 2012;41:752-62.

25. Chen WQ, Yu IT-S, Wong TW. Impact of occupational stress and other psychosocial factors on musculoskeletal pain among Chinese offshore oil installation workers. Occup Environ Med [Internet]. 2005 [cited 2014 July 12];62(4):251-6. Available from: http://www.ncbi. nlm.nih.gov/pmc/articles/PMC1740997/pdf/v062p00251.pdf

26. Steinsvag K, Bratveit M, Moen E, Kromhout H. Inter-rater agreement in the assessment of exposure to carcinogens in the offshore petroleum industry. Occup Environ Med [Internet]. 2007 [cited 2014 July 15];64(9):582-8. Available from: http://www.ncbi.nlm.nih.gov/pmc/ articles/PMC2092566/

27. Ruesta P, Roberto C. Determinación de los factores de riesgo cardiovascular en trabajadores a turnos en plataformas marítimas de una petrolera del Norte del Perú. Acta Med Per [Internet] 2011 [citado 2014 Jul. 15];28(2):67-72. Disponible en: http://sisbib.unmsm.edu.pe/ bvrevistas/acta_medica/2011_n2/pdf/a02v28n2.pdf

28. Chen WQ, Wong TW, Yu TS. Mental health issues in Chinese offshore oil workers. Occup Med (Lond). 2009;59(8):545-9.

29. Ljosa $\mathrm{CH}$, Tyssen R, Lau B. Mental distress among shift workers in Norwegian offshore petroleum industry: relative influence of individual and psychosocial work factors. Scand J Work Environ Health. 2011;37(6):551-5.

30. Kelsh MA, Morimoto L, Lau E. Cancer mortality and oil production in the Amazon Region of Ecuador, 1990-2005. Int Arch Occup Environ Health. 2009;82(3):381-95

31. Oenning NSX, Carvalho FM, Lima VMC. Indicadores de absenteísmo e diagnósticos associados às licenças médicas de trabalhadores da área de serviços de uma indústria de petróleo. Rev Bras Saúde Ocup [Internet]. 2012 [citado 2014 jul. 15];37(125):150-8. Disponível em: http://www.scielo.br/pdf/rbso/v37n125/a18v37n125.pdf

32. Waage S, Harris A, Pallensen S, Saksvik IB, Moen BE, Bjorvatn B. Subjective and objective sleepiness among oil rig workers during three different shift schedules. Sleep Med. 2012;13(1):64-72.

33. Carrasco JM, Pérez-Gómez B, García-Mendizábal MJ, Lope V, Aragonés N, Forjaz MJ, et al. Health-related quality of life and mental health in the medium-term aftermath of the Prestige oil spill in Galiza (Spain): a cross-sectional study. BMC Public Health [Internet]. 2007 [cited 2014 July 12];7:245. Available from: http://www.ncbi.nlm.nih.gov/pmc/articles/PMC2194772

34. Tsai SP, Bhojani FA, Wendt JK. Risk factors for illness absence due to musculoskeletal disorders in a 4-year prospective study of a petroleummanufacturing population. Occup Environ Med [Internet]. 2011 [cited 2014 July 12];53(4):434-40. Available from: http://www.ncbi.nlm. nih.gov/pubmed/21407094

35. Steinsvag K, Bratveit M, Moen BE. Exposure to carcinogens for defined job categories in Norway's offshore petroleum industry, 1970 to 2005. Occup Environ Med [Internet]. 2007 [cited 2014 July 12];64(4):250-8. Available from: http://www.ncbi.nlm.nih.gov/pmc/articles/ PMC2092566/

36. Lewis R, Schnatter A, Drummond I, Murray N, Thompson F, Katz A, et al. Mortality and cancer morbidity in a cohort of Canadian petroleum workers. Occup Environ Med [Internet]. 2003 [cited 2014 July 12];60(12):918-28. Available from: http://www.ncbi.nlm.nih.gov/ pmc/articles/PMC1740448/

37. Souza NSS, Carvalho FM, Fernandes RCP. Hipertensão arterial entre trabalhadores de petróleo expostos a ruído. Cad Saúde Pública [Internet]. 2001 [citado 2014 jul. 12]; 17(6):1481-8. Disponível em: http://www.scielo.br/pdf/csp/v17n6/6974.pdf 
38. Guedes CCP, Aguiar BGC. Discutindo e refletindo sobre a competência do enfermeiro offshore. Rev Enferm UER] [Internet]. 2012 [citado 2014 jul. 12];20(1):61-6. Disponível em: http://www.facenf.uerj.br/v20n1/v20n1a11.pdf

39. Brasil. Ministério da Saúde. Doenças relacionadas ao trabalho: manual de procedimentos para os serviços de saúde [Internet]. Brasília; 2001 [citado 2014 ago. 18]. Disponível em: http://www.opas.org.br/sistema/arquivos/Saudedotrabalhador.pdf

40. Neves HCC, Souza ACS, Medeiros M, Munari DB, Ribeiro LCM, Tipple FV. Safety of nursing staff and determinants of adherence to personal protective equipment. Rev Latino Am Enfermagem [Internet]. 2011 [cited 2014 July 12];19(2):354-61. Available from: http://www. scielo.br/pdf/rlae/v19n2/pt_18

41. Santos JLG, Erdmann AL, Andrade SR, Mello ALSF, Lima SBS, Pestana AL. Nursing governance: an integrative review of the literature. Rev Esc Enferm USP [Internet]. 2013 [cited 2014 Nov 18];47(6):1417-25. Available from: http://www.scielo.br/pdf/reeusp/v47n6/en_00806234-reeusp-47-6-01417.pdf 